\title{
English Language, Globalisation and the Future of the Nigerian Indigenous Languages
}

\author{
Eucharia Okwudilichukwu Ugwu,
}

Department of Arts and Social Sciences Education, University of Ibadan, Ibadan, Nigeria

Doi:10.19044/esj.2020.v16n14p38～URL:http://dx.doi.org/10.19044/esj.2020.v16n14p38

\begin{abstract}
In the present globalised world, languages have come to be ranked based on their roles in the world arena, the status assigned to them in the environment in which they are spoken as well as the number of their respective speakers. As such, some languages, including English, is considered a world language. English language wields great power in Nigeria, as an official and national language. Its ever-increasing roles have detrimental effects on the survival of the minority languages, with most of them playing just peripheral roles. Most of the minority languages are further threatened by the major ones spoken in different geopolitical zones. As the functional loads of these minority languages continue to reduce gradually and consistently, their level of vitality equally reduces. A minority language whose functional domains are overtaken by a dominant one will eventually disappear as their users shift to the latter and therefore, would no longer use them for any linguistic function. This paper discusses the current precarious situation of the Nigerian indigenous languages, especially the minority ones in the face of globalisation, the domineering effect of English language and what can be done to make these languages withstand the test of time.
\end{abstract}

Keywords: Language and globalisation, Indigenous languages, majority and minority languages, language endangerment in Nigeria, English language in Nigeria

\section{Introduction}

Just as human beings compete for the best and top positions in the world's socio-political and socio-economic arenas, so also do the languages, in the present globalised world. However, whereas human beings make conscious choices, the fate of the languages lie in the hands of their speakers who can decide to promote or demote them. Among the many choices that human beings make is that of linguistic choice, that is, which language to 
learn, speak and use for which or what purposes. Human beings also could decide to abandon a language they have spoken for years and then shift to another language for reasons best known to them. Such linguistic decisions or choices affect, and in fact, determine the survival and death of different languages, most especially the minority ones, in a multilingual setting like Nigeria. Relying on existing statistics, Ugwu (2019) discovered that Nigeria and Cameroon have the highest number of endangered and extinct languages in West Africa (p. 64).

This paper is an attempt to discuss the fate of the minority languages of Nigeria in the face of globalisation and the dominance of English language. Relying on existing empirical evidence, the paper also looks at the dynamics of language shift in Nigeria and how this affect the vitality of the numerous minority languages. Some suggestions on how to reverse the current trend were made for the survival of the minority languages so that they will not go into extinction in the near future.

\section{The Nigerian Linguistic Situation}

That Nigeria is a highly multilingual nation is without doubt. It is, in the words of Iwara (2008), a multilingual country par excellence with an exceptional linguistic situation. Out of the six major language families of the world, two are found in Nigeria (the Afro-Asiatic and the Niger-Congo). Other language families such as the Nilo-Saharan, Pidgin, Creole and Sign language are also present in Nigeria, with some from unclassified families (Simons and Charles, 2018). Summarizing the language situation in Nigeria, Eberhard, Gary, and Charles (2020) state that there are established 515 living languages in the country. Of this total, 505 are indigenous while 10 are non-indigenous. Among the indigenous languages, some are classified as majority while others are minority. The majority languages are three, namely, Hausa, Igbo and Yoruba. Hausa is a de facto provincial language in the northern region with over 53 million L1 and L2 users in Nigeria; Igbo is a de facto provincial language in the southeastern region with over 29 million speakers in Nigeria, and Yoruba is a de facto provincial language in the southwestern region with more than 42 million users in Nigeria (Eberhard, Gary, and Charles, 2020). These three languages have the advantages of more native speakers and more developed orthographies. The three have, over the years, also been promoted in the educational sector more than all the other Nigerian indigenous languages and were designated as national languages after Nigeria's political independence. Every other indigenous language in Nigeria such as the Tiv, Fulfude, Urhobo, Edo, Ibibio, Igala, Efik and Idoma comes under the minority grouping. Some of the minority languages have relatively large numbers of native speakers, standardized orthographies, and are recognised as official languages at the respective geographical units where they are spoken. 
However, among this group, some can also be considered as minor-minority in the sense that they have fewer numbers of speakers and lower status.

Among all the indigenous and non-indigenous languages spoken in Nigeria, English takes an almost enviable position, serving both as a national and sole official language. It has the highest number of speakers than any other language in Nigeria. Besides, it is assigned more functions than any, or in fact, all of the indigenous languages put together. It is the language of legislature and governance, education, mass media, wider communication, international relations, and of the legal system. In many Nigerian homes, especially among the educated elites and in the cities, it has become the language of daily communication. English is promoted in education more than any Nigerian language, serving as the medium of instruction from upper primary school to the tertiary level of education.

Officially speaking, the second in rank, among the non-indigenous languages is French, which is designated as Nigeria's second official language. French has prominence over most Nigerian languages in the educational sector, being a compulsory school subject both at the primary and junior secondary schools, a school subject at the senior secondary school and an academic discipline at the tertiary level (FRN, 2014). In some Nigerian universities, including the University of Ibadan, French is also a compulsory unit course (general studies programme) for all undergraduate students. Another non-indigenous language that features at all levels of education in Nigeria is Arabic. These three languages (English, French and Arabic) are imported, yet they have greater space in the educational sector than most of the indigenous languages. In the Senior School Certificate Examinations organized by the major examination bodies such as the West African Examination Council (WAEC) and the Nigerian Examination Council (NECO), the three are prominent arts subjects that are covered by the syllabus and many students take them every year. Meanwhile, only six Nigerian languages (Edo, Efik, Ibibio, Hausa, Igbo and Yoruba) are examined by the two bodies in their respective examinations (WAEC, 2018; NECO, 2016).

Another non-indigenous language that has become very prominent is the Nigerian Pidgin, which is a local non-standard variation of the English language. It is widely spoken in almost every part of Nigeria. Nigerian Pidgin enjoys a special unofficial status of lingua franca, especially in cosmopolitan cities and even in some rural areas where numerous languages exists. Apart from the fact that Nigerian Pidgin does not observe strict grammatical rules, some of its words are coined from the indigenous languages, thus making it easier to learn than English by even the illiterates and semi-literates. It is spoken by up to 45 million people in Nigeria (Eberhard, Gary, and Charles, 2020). In spite of its popularity, those who speak Nigerian Pidgin cannot be classified as proficient in English language, even though, for a great majority, 
it serves as a communicative bridge that could link them with the literates. In order to find a footing in a society where English dictates the order of the day in most official settings, Pidgin is indeed a harbour for many Nigerians as it enables them to have a say or to understand what is going on in the wider society. Although considered a lingua franca, there are still millions of Nigerians who cannot speak it but rely solely on their native languages for daily communication.

With more prominence given to English in the Nigerian educational and political sectors, those who are not proficient in it are bound to be disadvantaged. Being a second language to most Nigerians, learning English language is not easy because it requires formal settings such as in schools. Meanwhile, the indigenous languages are not widely or seriously promoted like the English language in the educational sector. For example, in the Nigerian National Policy on Education (NPE), the indigenous languages can only be used for instruction at the lower level of primary school (that is, primary classes 1-3) (Federal Republic of Nigeria, FRN, 2014, p. 11). Thus, the policy itself has a limiting effect on the status of the indigenous languages.

\section{The Situation of the Nigerian Languages}

In multilingual settings, language choice, that is, the tendency to choose one language over another for different purposes is inevitable. According to Igboanusi (2008a), language choice exists both as the societal and individual levels. The envisaged utilitarian values of a language would tend to increase speakers choice to learn or use it. In other words, a language that seems to have more utilitarian values will most likely attract or retain more speakers than those that are perceived to have less. Identified factors that could make speakers to stick to a given language or learn it may include globalisation, attitude, family, ethnic identity, religious affiliation, education, politics and language policy (Dweik and Qawar, 2015; Igboanusi, 2008a; Romaine, 2015; Ugwu, 2019; Ugwu, 2020). Since the choice to use one language could entail not using the other, the preferred one would be gaining speakers just as the one not preferred would be losing. This trend, that is, choosing one language over another could lead to the endangerment or extinction of the less-preferred language (Ugwu, 2020). Hence, many Nigerian languages are presently endangered or near-extinction as their users shift to either English or the majority indigenous languages. The summary of a threeyear update on the situation of the Nigerian languages $(2018-2020)$ is represented on table 1 . As shown on the table, whereas the languages classified as "institutional" remain constant for the three years, those categorised as developing, vigorous, in trouble and dying are constantly changing. Languages classified as institutional are the safest because they have been developed and are used in different domains outside the home and speech 
community. Worthy of note is the fact that over 40 languages that were under the developing category in 2018 degenerated to the vigorous category in 2019 and 2020. Besides, more languages are in trouble in 2019 and 2020 than in 2018. In terms of the level of language vitality, table 1 equally shows that in year 2020, more than 100 Nigerian languages are endangered, over 350 of them are stable, that is, used at home, learned by children, but no further strong measure is in place to sustain them. This does not present a promising future for these languages.

While there are different causes of language endangerment in Nigeria, domination by English language both within the country and in the world's linguistic arena (as a world language, language of globalisation and of science and technology, etc.) is undeniably a major contributing factor. As pointed out earlier, English language has been assigned far more roles in Nigeria than any of the indigenous languages in almost all major public domains. In the face of the current reality of language endangerment in the world, Ugwu (2017) states that most Nigerian languages can no longer withstand the test of globalisation, unless drastic measures are taken to safeguard them.

When a language is denied a space in key public areas, both their utilitarian values and number of speakers would tend to thin down. Not only would such languages not be able to gain more speakers but also, their speakers might begin to shift to other languages which have more roles in the society, are used for wider communication and could guarantee access to information and other linguistic needs. This is presently the fate of many Nigerian indigenous languages. Moseley (2010) had observed that in Nigeria, Pidgin English has developed into a creole and is replacing other indigenous languages as a new mother tongue (p. 21). More so, English language, by virtue of its being a world language has come to be regarded as the language of globalisation. For this reason, many Nigerians (especially the younger generation) are shifting to it in order not to be left behind in the fast-growing world. Research evidence has shown a preference for English as the sole medium of instruction in many Nigerian schools (Bilewumo, 2008; Ezeokoli and Ugwu, 2019). While it is important to learn English so as to be able to participate in the national life and connect with the outside world, this ought not to be done at the expense of the indigenous languages. A continuous shift to English means a continued decline in the number of speakers of the indigenous languages. In Nigeria, over-reliance on English in most public domains has also tended to retard the development of the indigenous languages. As shown on Table 1, the fact that the number of languages classified as "institutional" did not increase within the three years implies that little or no effort was made to make more indigenous languages develop to the extent of being added to that category. 
A proposition made by Pandharipande (2002) concerning how majority languages (in India) could threaten the survival of the minority ones can be used to understand the current situation of many Nigerian languages and how they are being threatened by English language. According to the author, there is a strong correlation between the functional loads assigned to any language and its chances of survival such that, the higher the functional loads a language has, the better chances its survival is guaranteed and vice versa. Thus, the attrition of minority languages equally has a direct link to their reduced functional loads as well as their lack of functional transparency. A language is considered functionally transparent if it is the only language used to perform a particular function in a particular domain and the more functionally transparent a particular language is, the higher functional loads it would also possess. Pandharipande (2002) established four relatively high/low degrees of functional load, namely:

1. + functional transparency + number of domains

2. + functional transparency - number of domains

3. - functional transparency + number of domains

4. - functional transparency - number of domains

The first degree implies that a language has functional transparency and is used in different domains. The second category implies that a language has functional transparency but used in reduced number of domains when compared to those in the first category. The third implies that a language is not functionally transparent in any domain; in other words, there is no function it is performing solely but is rather competing with other languages in all the functions it performs. A language in this third category would need to struggle to retain its speakers. Finally, in the fourth category, the language is neither functionally transparent nor used in any domain. In that case, the language is really in trouble, risks losing its speakers and going into extinction in due course.

Applying the above-mentioned proposition to the linguistic situation in Nigeria, English language is functionally transparent in many domains, such as in education where it serves as the sole medium of instruction from the upper primary through secondary and up to the tertiary levels of education. However, at the lower primary school level (that is, 1-3), the medium of instruction is the mother tongue or language of immediate environment in monolingual communities (FRN, 2014:11). If this policy is adhered to strictly, it would mean that as many indigenous languages as are used for instruction could have the advantage of being functionally transparent in their respective settings at least at that level of education. Languages in this category (that is, used presently for educational purposes in Nigeria) include Tiv, Edo, Ga'anda, Emai-luleha-Ora, Igala, Izon, Idoma, Urhobo, Ibibio, Kanuri (Yerwa), Efik as 
well all the three major languages (Hausa, Igbo and Yorba) (Eberhard, Gary, and Charles, 2020). If all the above-listed languages share the same function, (that is, used as mediums of instruction at the lower level of primary school), none of them is functionally transparent in that domain at the national level. Besides, research has shown that even at that level, it is not all schools that implement the policy (Okebukola, Owolabi and Okebukola, 2012; Adeyemi and Ajibade, 2014) and the government hardly monitors the schools to ensure that the policy is implemented (Obiegbu, 2016). Hence, only English language enjoys the status of functional transparency (in education) at the national level - not only in the educational sector but also in most socio-political and socioeconomic domains. For instance, although three indigenous languages (Hausa, Igbo and Yoruba) have constitutional backings to be used alongside English in carrying out the 'business of the Nation Assembly... when adequate arrangements have been made therefore' (The Federal Republic of Nigeria, 1999, Article 55), English has remained predominant in most political debates and there is no known arrangement being made to accommodate the indigenous languages.

Furthermore, the three major and some of the major-minority Nigerian languages fall within the second category (that is, + functional transparency number of domains), by virtue of their being functionally transparent in limited areas and having some functional loads. For instance, many indigenous languages remain the medium of interaction at homes, in the market places, churches and within numerous rural communities. However, even in these remote areas, English is gradually creeping in to compete with the indigenous languages as children are made to receive education solely in English. Besides, English is the official language and the citizens cannot do without it. Education delivered solely in English could reduce children's interest in learning or speaking their mother tongues and other Nigerian languages.

\section{Language Shift in Nigeria: A Major Concern}

In any society where one or some languages are assigned higher status than the rest, there always will be the tendency for speakers to shift to those ones with higher status, most especially if the ones with lower status are also minority languages. This often results to reduced functional loads of the languages with lower status. In Nigeria, English is undeniably the most prestigious language with the highest status; thus, it is also the greatest threat to both the majority and the minority languages (Ezenwa-Ohaeto and Akujobi, 2013; Haruna, 2017; Sarvi, 2012). Among the indigenous languages, the highest in status are the three national languages (Hausa, Igbo and Yoruba); these have larger numbers of speakers and relatively-more developed orthographies. While all the three are threatened by English language, Hausa appears to be a threat to more indigenous languages than the other two. Its 
domineering influence is prominent in the northern geopolitical zones (north east, north central and north west). A study by Wayar (2017) showed that Babur/Bura, an indigenous language spoken in Adamawa and Borno States (north east) is threatened by Hausa. The functional loads of Bura have drastically reduced, including in situations where it is the first language of the interlocutors and one would ordinarily expect that they communicate with it. This, the author claims, is irrespective of the fact that Bura is one of the majorminority languages in the north east. If such a language could be threatened by Hausa, many minor-minority languages within the area might be in a more precarious situation. Under the Expanded Graded Intergenerational Disruption Scale (EGIDS), Bura falls under Grade 6b, which implies that it is really threatened and that although children still speak it, the extent of intergenerational transmission is weak and may be broken if no action is taken to reverse the trend (Eberhard, Gary, and Charles, 2020).

Furthermore, in Gombe and Yobe States (also north east), both Hausa and English threaten the survival of Bole, an indigenous language spoken in the two States (Haruna, 2017). According to the study, most students to whom Bole was supposed to be their first language no longer understand or speak it but use Hausa instead. Among the sampled group, $25 \%$ of them communicate with their fellow Bole friends on social media in Hausa, 12.5\% use English, over 50\% combine Hausa and English and only $12.5 \%$ use Hausa and Bole. Moreover, only a few, (12.5\% of the respondents) could write their names and addresses in Bole language. English and Hausa have also been identified as threats to Eggon, an indigenous language spoken in Nasarawa State (north central) (Sarvi, 2012). The language is no longer used in new domains, (that is to say, its areas of use are shrinking, rather than expanding) because most of its native speakers are shifting to Hausa and English language. However, under the EGIDS, both Eggon and Bole are in level 6A, which implies that although they are unstandardized, they are still vigorously used by all generations (Eberhard, Gary, and Charles, 2020).

Similarly, at the north central geopolitical zone, Adewale and Oshodi (2013) discovered that Hausa threatens the survival of six minority languages spoken in Niger State: Ura, Lupa, Kaami, Gelanci, Bangi and Asu. The study showed that speakers of these languages - children, youth and adults prefer speaking Hausa, as a result of which the above identified languages are presently near extinction. The author further noted that instead of the speakers to embrace the major-minority languages around their environment such as Nupe, Gwari and Kamuku, they rather opt for Hausa. This is an indication that Hausa wields greater linguistic power over the rest in the north. Similar findings were made by Agantiem (2017) who reported that Hausa is a threat to the indigenous languages in Kano State, Kebbi State, Jigawa State and Sokoto State. According to the findings, the different local languages that exist 
within these States 'are hardly heard of beyond their vicinities' because Hausa has taken over as the language of communication by their speakers. The causes of speakers' shift to Hausa have been attributed to religion, unfavourable language policy which has given Hausa higher prestige, envisaged economic and socio-political advantages. Other factors include negative attitude towards the minority languages, limited number of speakers as well as their restricted domain of use (Adewale and Oshodi, 2013; Sarvi, 2012; Wayar, 2017). Igboanusi, (2008b) asserts that association with Hausa gives the minority groups in the north both economic and political advantage; for that reasons, they shift to it without minding that such action threatens the survival of their own languages.

Apart from the northeast region, threat to the indigenous languages also exists in other parts of Nigeria. This is all the more heightened in the cosmopolitan town and cities. Ugot and Ogar (2014) believe that some languages in Cross River State (south-south geopolitical zone) are threatened due to assimilation by larger groups. This includes the Akam language, a variety of Mbembe, spoken by a small village between Ofutop and Ikom. Language shift or assimilation is taking place as Akam is being assimilated into Ejagham due to language contact. Three other languages: Kiong, Bakpinka and Odut are heading to attrition. In the EGIDS, Kiong is classified as moribund (8A), Odut as nearly extinct (8B) and Kiong as moribund (9) that is to say, there is no more any known L1 speaker of it) (Eberhard, Gary, and Charles, 2020). Thus, the three languages, if at all they are still in existence, may actually go into extinction at any moment, having reached an irreversible stage of language endangerment. Moreover, the Qua dialects of Ejagham and the Efut language spoken in Calabar are also threatened by Efik. Ejagham is in Grade 5, under the EGIDS, meaning that it is vigorous and standardised. Moreover, in Calabar, Efik language has become the lingua franca and thus threatens the survival of the minority languages, most especially Efut and the Qua (Agantiem, 2017). The author believes that the Efut language may have been lost because only the very elderly people use it for special purposes.

Another source of threat comes from both English and its variation, the Pidgin English which is predominantly spoken in some states in Nigeria such as Delta, Edo, Rivers and Cross River States. In the Niger Delta region or example, a combination of language contact and other social factors are contributing to the endangerment of some minority languages. Ayenbi (2014) links the threat to Ishekiri language to factors such as the spate of wars in the oil rich region, insecurity arising from interethnic crises which make speakers afraid to be identified by a particular language, mixed marriages as well as the need to communicate with the wider community. These factors combine to 
make speakers predominantly speak Pidgin English, which has become the lingua franca and is more cosmopolitan.

While it might be easy to conclude that the need for a more cosmopolitan language in multilingual situations is the major cause of language shift in Nigeria, this is not always the case. In predominantly monolingual communities, the major threats to the indigenous languages are English and Pidgin. This is the situation in the southeast where Igbo is predominantly spoken. Commenting on English as a threat to Igbo language specifically, Ezenwa-Ohaeto and Akujobi (2013) observe that the use of English language has become a common place that some natives, especially children and youths, cannot confidently and fluently interact in their own native language.

However, education is also a major contributor to language shift - from the local to English language in Nigeria. As the major language of education, passing it at a credit level in the Senior School Certificate Examination is a prerequisite for admission into tertiary institutions. Although the NPE recommends teaching through the medium of the mother tongue or language of environment at the nursery and lower primary schools, what is presently obtainable is a predominant use of English language at all levels. A study by Ezenwa-Ohaeto and Akujobi (2013) shows that English is used for instruction at the pre-nursery and nursery levels of education, learners are punished or reprimanded for speaking Igbo in the school premises, school authorities not only encourage but insist that parents speak English to their children even at home and teachers believe that the earlier children are exposed to English language, the more proficient they would be in the it. Other studies, including Kehinde and Taiwo (2016), Osoba and Alebiosu (2016) have shown a preference for English to the indigenous languages among Nigerians. Moseley (2010) had predicted that Pidgins and Creoles are the youngest and fastestgrowing languages on the African continent and will play important roles at replacing languages (p. 22). Ayakoroma (2017) points out that unless the Nigerian indigenous languages are made functional and relevant to their users by the government, both at local and state levels, all efforts at reviving their use in the society will amount to nothing. The native speakers will continue to shift to the dominant languages so long as the latter are given higher status than the former. In other words, the value the speakers will place on their languages will always depend on how much power such languages have in the larger society. However, if these indigenous languages are to withstand the competition of the changing world, they must be developed and promoted in schools through the formulation of a practical language policy (Ugwu, 2017). 


\section{Recommendations and Conclusion:}

Nigerian indigenous languages are great cultural heritage bequeathed on the citizen by the previous generations. The onus of preserving them for the upcoming generations would depend on the choices made by the present generation, given the competitive nature of languages in the present world. Using as many indigenous languages as possible in education will help to increase their status, quicken and enhance their standardisation and enable them survive the threats of globalisation. Preserving these languages would help to harness their rich potentials and cultural values in the society. For these languages to remain relevant now and in the future, concrete possible actions that could be taken include, but are not limited to:

1. Training more teachers of indigenous languages so that they in turn could teach the languages in schools.

2. Fostering the use of as many of the indigenous languages as possible in education at all levels. This includes studying them as school subjects and accommodating them in the external examinations (especially WAEC, NECO and the Unified Tertiary Matriculation Examination - a qualifying examination for enrolment into Nigerian tertiary institutions). If this is done, more of them will eventually develop to the point of being used as mediums of instruction beyond the lower primary school.

3. Ensuring that the use of the mother tongue or language of the environment (as stipulated in the National Policy on Education) is strictly adhered to at the pre-primary and primary schools. This would include monitoring the schools to ensure full compliance and sanctioning those that fail to comply. However, adequate measures need to be put in place for this to be feasible. For example, there has to be properly-trained and well-motivated teachers, textbooks, instructional aids and conducive environments.

4. Increasing the status of the indigenous languages both at the local levels where they are spoken and within their geopolitical zones. This may include making an indigenous language within a geopolitical zone compulsory for studying certain courses in all federal and state universities located within that same zone. Furthermore, at least one indigenous language could be made a compulsory course unit (general studies) for all undergraduate students as is done with French in some Nigerian universities presently.

5. Embarking on mass campaigns, especially through the digital media and technology to help change the negative attitude of the citizens towards their indigenous languages. This may include enlightening them on the beauty and values of their languages and the need to preserve them. 
6. Supporting the efforts of the indigenous people to make their languages count in different domains.

Table 1: 3-year update on the situation of Nigerian language

\begin{tabular}{|c|c|c|c|c|c|c|c|c|c|}
\hline \multirow[t]{3}{*}{ Year } & \multirow[t]{3}{*}{ Living } & \multirow[t]{3}{*}{ Extinct } & \multirow[t]{3}{*}{ Indigenous } & \multirow{3}{*}{$\begin{array}{c}\text { Non- } \\
\text { Indigenous }\end{array}$} & \multicolumn{5}{|c|}{ Status of Nigerian Languages } \\
\hline & & & & & \multirow[b]{2}{*}{ Institutional } & \multicolumn{2}{|c|}{ Stable } & \multicolumn{2}{|c|}{ Endangered } \\
\hline & & & & & & Developing & Vigorous & $\begin{array}{c}\text { In } \\
\text { trouble }\end{array}$ & Dying \\
\hline 2018 & 519 & 7 & 509 & 10 & 19 & 78 & 348 & 30 & 44 \\
\hline 2019 & 517 & 8 & 507 & 10 & 19 & 76 & 299 & 81 & 42 \\
\hline 2020 & 515 & 9 & 505 & 10 & 19 & 76 & 299 & 82 & 39 \\
\hline
\end{tabular}

Source: Simons and Charles (2018); Eberhard, Gary, and Charles, (2019); Eberhard, Gary, and Charles (2020)

\section{References:}

1. Adewale, R. K. and Oshodi, B. (2013). Language endangerment in Nigeria: Focus on small ethnolinguistic communities in Niger state. Dialectologia, 11, 17-45

2. Adeyemi, B. B. and Ajibade, Y. A. (2014). Degree of implementation of the language provisions in primary and secondary schools in southwestern Nigeria. World Journal of Education, 4(4), 92-104. www.sciedu.ca/wje

3. Agantiem, A. A. ( 2017). Language (in) equality, language endangerment and the threats to Nigerian languages. Journal of Literature, Languages and Linguistics, 37, 21-28. www.iiste.org

4. Ayakoroma, B. F. (2017). Reviving the use of indigenous languages in the contemporary Nigerian society: The National Institute for Cultural Orientation (NICO) Initiative. International Journal of Language and Linguistics, 4(4), 182-188.

5. Ayenbi, O. F. (2014). Language regression in Nigeria. Éducation et sociétés plurilingues, 36, 51-64. URL: http://esp.revues.org/136

6. Bilewumo, J. O. (2008). Attitude towards the use of the mother tongue or English as medium of instructions: its implication on literacy development. In O. Emejulu, L. Uwatt \& A. E. Arua (Eds.), Topical Issues in Literacy, Language and Development in Nigeria (pp. 39-53). Newark, DE: International Reading Association.

7. Dweik, B. S. and Qawar, (2015). Language choice and language attitudes in a multilingual Arab Canadian community: QuebecCanada: A sociolinguistic study. European Centre for Research Training and Development $U K, 3(1), 1-12$.

8. Eberhard, D. M., Gary F. S., and Charles, D. F. (eds.). (2019). Ethnologue: Languages of the World. $22^{\text {nd }}$ edition. Dallas, Texas: SIL International. Online version: http://www.ethnologue.com. 
9. Eberhard, D. M., Gary F. S., and Charles, D. F. (eds.). (2020). Ethnologue: Languages of the World. $23^{\text {rd }}$ edition. Dallas, Texas: SIL International. Online version: http://www.ethnologue.com.

10. Ezenwa-Ohaeto, N. and Akujobi, O. S. (2013). English as a second language in contemporary Nigerian society, a reality or farce? Awka Journal of English Language and Literary Studies, 4(1), 45-60.

11. Ezeokoli, F. O. and Ugwu, E. O. (2019). Parents', Teachers' and students' beliefs about the use and study of mother-tongue in the secondary schools in Akinyele Local Government Area, Oyo State, Nigeria. International Journal of Education \& Literacy Studies, IJELS 7(2), 82-93. http://dx.doi.org/10.7575/aiac.ijels.v.7n.2p.82

12. Haruna, H. H. (2017). Linguistic diversity and language endangerment: towards the revitalisation of Bole language in Nigeria. International Journal for Innovative Research In Multidisciplinary Field. 3(10), 108-113.

13. Igboanusi, H. (2008a). Changing trends in language choice in Nigeria. Sociolinguistic Studies, 2(2), 258-269. Doi : 10.1558/sols.v2i2.251

14. Igboanusi, H. (2008b). mother tongue-based bilingual education in Nigeria: Attitudes and practice. The International Journal of Bilingual Education and Bilingualism, 11(6), 721-734. Doi: 10.1080/13670050802149291

15. Iwara, A. U. (2008). The Linguistic Situation in Nigeria and its Implication for Sustainable Development. An Inaugural Lecture. Ibadan: Ibadan University Press.

16. Kehinde, A. A. and Taiwo, O. S. (2016). Mother Tongue eclipsing in the linguistic repertoire of Yoruba/English bilingual children in Nigeria, Legon Journal of the Humanities, 27(1), 95-118. DOI: http://dx.doi.org/10.4314/ljh.v27i1.5

17. Moseley, C. (ed.). (2010). Atlas of the World's Languages in Danger, 3rd edition. Paris: UNESCO Publishing. Retrieved from www.unesco.org/culture/en/endangeredlanguages

18. Mufwene, S. S. (2002). Colonisation, globalisation, and the future of languages in the twenty-first century. International Journal on Multicultural Societies (IJMS), 4(2), 162-193. Retrieved from www.unesco.org/shs/ijhm/vol4/issue2/ed

19. National Examination Council, NECO. (2016). June/July Senior School Certificate Examination (SSCE) Examination Time-Table. Retrieved from https://waectimetable.org.ng/neco-ssce-timetable/

20. Obiegbu, I. (2016). Mother tongue education: A panacea to effective teaching and learning of English in Nigeria primary schools. Research on Humanities and Social Sciences, 6(16), 93-97. 
21. Okebukola, P. A, Owolabi, O. and Okebukola, F. O (2012). Mother tongue as default language of instruction in lower primary science classes: Tension between policy prescription and practice in Nigeria. Journal of Research in Science Teaching, 50(1), 62-81. Doi: https://doi.org/10.1002/tea.21070

22. Osoba, J. B. and Alebiosu, T. A. (2016). Language preference as a precursor to displacement and extinction in Nigeria: the roles of English language and Nigerian Pidgin. Journal of Universal Language, 17(2), 111-143.

DOI: https://doi.org/10.22425/jul.2016.17.2.111

23. Pandharipande, R. V. (2002). Minority matters: issues in minority languages in India. International Journal on Multicultural Societies (IJMS), 4(2), 213-234. Retrieved from

http://unesdoc.unesco.org/images/0013/001387/138795E.pdf

24. Romaine, S. (2015). The global extinction of languages and its consequences for cultural diversity. In H. F. Marten, M. Riessler, J. Saarikivi, and R. Toivanen, (eds.). Cultural and Linguistic Minorities in the Russian Federation and the European Union. Switzerland: Springer International Publishing. pp. 31-4. Retrieved from http://www.springer.com/cda/content/document/cda_downloaddocum ent/9783319104546-c2.pdf?SGWID=0-0-45-1492462-p176900229

25. Sarvi, S. A. (2012). An assessment of level of language endangerment in Nigeria: A study of Eggon Language of Nasarawa State. An unpublished $\mathrm{PhD}$ Thesis. Department of African Languages and Cultures, Faculty of Arts, Ahmadu Bello University, Zaria, Nigeria. Retrieved from http://kubanni.abu.edu.ng/jspui/bitstream/123456789/8835/1 /AN\%20ASSESSMENT\%200F\%20LEVEL\%200F\%20LANGUAG E\%20ENDANGERMENT\%20IN\%20NIGERIA\%20A\%20STUDY $\% 200 F \%$ 20EGGON\%20LANGUAGE\%200F\%20NASARAWA\%2 OSTATE.pdf

26. Simons, G. F. and Charles, D. F. (eds.). (2018). Ethnologue: Languages of the World, $21^{\text {st }}$ edition. Dallas, Texas: SIL International. http://www.ethnologue.com

27. The Federal Republic of Nigeria (2014). National Policy on Education.

28. The Federal Republic of Nigeria (1999). Constitution of the Federal Republic of Nigeria.

29. Ugot, M. and Ogar, M. N. (2014). Language and Power in Cross River State, Nigeria. Mediterranean Journal of Social Sciences. 5(10), 648656. 
30. Ugwu, E. O. (2019). Africa on the verge of a linguistic genocide: The need for action. European Scientific Journal, 15(23), 57-75. Doi:10.19044/esj.2019.v15n23p57

31. Ugwu, E. O. (2017). Promoting Nigerian languages beyond the $21^{\text {st }}$ century: problems and prospect. In D. O. Fakeye, S. A. O. Oladunjoye, I. A. Alade, B. O. Kayode-Olawoyin, O. R. Bateye, S. O., Olatunji, and O. S. Jayeoba (Eds.). Further Thoughts on Language, Education, and the Curriculum Nexus for Sustainable Development in Nigeria. Ibadan: Constellation Books. Pp.107-145.

32. Ugwu, E. O. (2020). Preserving language diversity for sustainable development in Nigeria European Scientific Journal, 16(11), 83-95. Doi:10.19044/esj.2020.v16n11p83

33. Wayar, B. (2017). Language Shift among the Babur/Bura speakers of Northern Nigeria. Merit Research Journal of Education and Review, 5(8), 080-086. Retrieved from http://www.meritresearchjournals.org/er/index.htm

34. West African Examination Council, WAEC. (2018). e-Learning. Retrieved from https://waeconline.org.ng/e-learning/index.htm 